\title{
Functions and contexts of Bronze Age metal casting moulds from Poland
}

\author{
Justyna Baron, Beata Miazga and Kamil NowaK
}

\begin{abstract}
Metal casting moulds, designed mostly to produce only one type of artefact, are a fascinating group of artefacts that have been recorded in many parts of Bronze Age Europe. Despite some examples of moulds for ornaments, the use of metal moulds is strongly connected with axe production. Moreover, most of the moulds were deposited deliberately in bogs and rivers in a similar way as axes. A recent find of such a mould from Gaj Oławski in southwestern Poland inspired us to bring together a small collection of bronze casting moulds from Poland. In our study, we focus on the contexts and possible functions of metal casting moulds with a particular focus on the recent find. Metal casting moulds dated back to the Bronze Age are rare in Poland with only five examples of such finds known to date. Such moulds were discovered at Pawłowiczki, Brzeg Głogowski, Kiełpino and Rosko. Their distribution is random even if the sites occur only in western Poland they are too few to speak of any pattern of deposition (fig. 1). A complete, two-piece item from Pawłowiczki — probably part of a deposit — was found in 1869; however, the precise location is unknown. Based on the axe's characteristics, the mould can be dated to the 5th period of the Bronze Age (i.e. ca. 900-700 BC). At Brzeg Głogowski, a complete two-piece mould was found, however no details of its discovery are known. Together with the mould, a complete socketed axe was found which had been cast in this mould (fig. 4d). As at Pawłowiczki, this mould can be dated to the 5th period of the Bronze Age (i.e. ca. 900-700 BC). The bog hoard from Kiełpino was discovered in 1884, and among a number of bronze ornaments and elements of horse gear, an iron knife and a lump of iron ore, there were also two complete two-piece moulds and two socketed axes that fitted them. The deposit from Rosko consists mostly of bronze socketed axes decorated with vertical ribs (67 items), and two, two-piece bronze casting moulds (figs. 5, 6), which makes the deposit an excellent example of selected deposition. The deposit contained mostly axes that were typical for large parts of south-western Poland and may be dated to ca. 900-700 BC. According to an opinion that is common in Polish sources, metal casting moulds, due to their low resistance to high temperatures, were used exclusively for making wax or lead models and not bronze products themselves. The archaeometric investigation's aim was to identify both the chemical composition of the mould (including the alloy's main elements and the molecular composition of the corrosion layers), and the original purpose of the item. There are two types of data obtained for the mould from Gaj Oławski. One group refers to the mineralogical composition of the item and proved the relative low tin content of it. The result corresponds with the opinion that the axes-regarding the alloys and casting techniques - display relatively lower quality. This also fits the view that the low tin content may indicate better resistance against high temperatures and direct metal casting. The other group of data refer to the black residue from the mould which is ancient beeswax remains. The analysed specimen yielded traits that correspond well with identified archaeological samples of beeswax. The discussed mould from Gaj Oławski displays properties allowing it both to be used to cast metal (reflected in the low tin content) and wax (beeswax remains), which makes it a good example of a multi-purpose tool used in various conditions. On the other hand, the wax can represent the remnants of coating used as a layer preventing the welding of mould with poured liquid metal, which would mean that the mould was covered with coating but was not fired.

Considering the context and the interpretation, the discussion on bronze casting moulds is strongly connected with the discussion on bronze deposits in general. The known locations allow us to consider the bronze casting moulds as objects of deliberate, and usually selective deposition, mostly in what can be described as 'offering contexts', including river, bog and hilltop finds. In his detailed study on depositional patterns and contexts, D. Fontijn argues that axes, sickles and weapons were kept away from graves, deposited somewhere else, mostly in what may be broadly understood as 'wet areas' (Fontijn, 2002, tables 10.1 and 10.2). Although his study concerns the Netherlands, it seems to fit the situation from other areas as well. Similar conclusions with a particular focus on river and bog finds in Poland were presented by J. Woźny (1996). He argues that the composition of water deposits in the Bronze and Early Iron Age in Poland reflects a clear opposition between weapons/tools and ornaments (Woźny, 1996, p. 89).

Recent publications on bronze deposits in Poland reflect a move away from purely economic interpretations to more complex views including significant examples of 'votive offerings' (Blajer, 2001, pp. 298-299), with many examples connected with bog and river contexts (e.g., Woźny, 1996 and 1997). Among five Polish sites with the moulds, three
\end{abstract}


were bog deposits (Kiełpino, Gaj Oławski, and indirectly Rosko) while for the other two, no information is available and thus similar contexts cannot be excluded. The three sites with known water contexts are located in a lowland area where the number of tools deposited in water increase towards the end of the Bronze Age. When the contexts of the moulds and axes are compared, it is clear that both were given similar significance, i.e. the moulds were treated like tools (axes) and deposited in the same way.

Keywords: casting mould, Bronze Age, deposit, Poland, beeswax.

Résumé : Les moules en métal, élaborés essentiellement en vue de produire un seul type d'artefact, constituent un groupe d'objets fascinant qui a été documenté dans beaucoup de régions de l'Europe à l'âge du Bronze. Bien qu'il existe des exemples de moules ayant été destinés à la fabrication de parures, l'usage de moules métalliques est très fortement lié à la production de haches. De plus, la plupart des moules ont été déposés intentionnellement dans des tourbières et des cours d'eau, d'une manière similaire aux haches. La découverte récente d'un moule de ce type, à Gaj Oławski dans le Sud-Ouest de la Pologne, nous a amenés à rassembler la petite collection de moules métalliques de Pologne. Cette étude est centrée sur les contextes et les fonctions possibles des moules en métal avec un focus particulier sur la récente découverte. Les moules métalliques datés de l'âge du Bronze sont rares en Pologne avec seulement cinq exemplaires connus à ce jour. Ces moules ont été découverts à Pawłowiczki, Brzeg Głogowski, Kiełpino et Rosko. Leur répartition est aléatoire. Même si les découvertes sont localisées dans l'Ouest de la Pologne, elles sont trop rares pour discuter d'un schéma de déposition (fig. 1). Un exemplaire complet, avec ses deux valves, a été découvert à Pawłowiczki en 1869 et faisait préalablement partie d'un dépôt; sa localisation précise est toutefois inconnue. D'après les caractéristiques de la hache, le moule peut être daté de la cinquième période de l'âge du Bronze (c'est-à-dire entre 900 et 700 avant notre ère). À Brzeg Głogowski, un moule complet, bivalve lui aussi, a été découverte mais aucune information sur le contexte de découverte n'a été conservée. Associée à ce moule, a été découvert une hache à douille complète, qui a été fabriquée dans ce même moule (fig. 4d). Comme à Pawłowiczki, ce moule peut être daté de la cinquième période de l'âge du Bronze (vers 900-700 avant J.-C.). Le dépôt en tourbière de Kiełpino a été découvert en 1884. Parmi de nombreux éléments de parure de bronze et de pièces de harnachement de cheval, un couteau en fer et un morceau de minerai de fer, il y avait aussi deux moules complets, tous les deux bivalves, et deux haches à douille qui leur correspondaient exactement. Le dépôt de Rosko est principalement composé de haches à douille en bronze décorées de nervures verticales et deux moules bivalves (fig. 5 et 6), ce qui montre très bien son caractère sélectif. Aucune des haches ne correspond aux moules, qui ont du coup été interprétés comme ayant été utilisés pour la production de modèles en cire. Sur l'une des pièces, l'empreinte d'une étoffe tissée a été identifiée et a été publiée par ailleurs (Sikorski, 2006). Le dépôt contenait pour l'essentiel des haches typiques d'une grande partie du Sud-Ouest de la Pologne et peuvent être datées d'environ 900-700 avant notre ère.

Selon une opinion assez usuelle dans la littérature archéologique polonaise, les moules en bronze, en raison de leur faible résistance aux hautes températures, étaient utilisés exclusivement pour produire des modèles en cire ou en plomb et non pas pour fabriquer directement des produits en bronze. Le but de l'analyse archéométrique était d'identifier à la fois la composition chimique du moule (ce qui inclut les éléments principaux de l'alliage et la composition moléculaire des niveaux de corrosion), et la finalité originelle de l'objet. Deux types de données ont été obtenus pour le moule de Gaj Oławski. Les premières correspondent à sa composition minéralogique et montrent un niveau d'étain relativement bas. Ce résultat conforte l'opinion que les haches - du point de vue des alliages et des techniques - présentent une qualité relativement basse. Ceci concorde également avec le point de vue selon lequel la faible proportion d'étain pourrait indiquer une meilleure résistance aux hautes températures et à la fusion directe du métal. Le deuxième groupe de données concerne le résidu noir dans le moule, qui s'avère être un reste ancien de cire d'abeille. Le spécimen analysé présentait des caractéristiques qui correspondent bien à des exemplaires archéologiques de cire d'abeille précédemment identifiés. Le moule de Gaj Oławski présente des propriétés lui permettant d'être utilisé aussi bien pour la fonte du métal (ce qui est reflété par le faible niveau d'étain) que pour la mise en forme de la cire (restes de cire d'abeille), ce qui en ferait un bon exemple d'outil multifonctions. D'un autre côté, la cire peut représenter les restes de l'enduit utilisé comme une couche intermédiaire empêchant la fusion du moule lors du versement du métal liquide, ce qui voudrait dire que le moule était couvert par l'enduit mais non chauffé.

Étant donné le contexte et son interprétation, la discussion sur les moules métalliques est fortement liée à celle sur les dépôts de bronze en général. Les lieux de découverte connus nous permettent de considérer les moules métalliques comme des objets ayant fait l'objet d'un dépôt intentionnel et généralement sélectif, principalement au sein de ce qui peut être décrit comme des contextes d'offrande, incluant les découvertes en cours d'eau, tourbières et sites de hauteur. Dans son étude détaillée sur les modalités et les contextes de dépôt, D. Fontijn argumente que les haches, les faucilles et les armes étaient exclues des sépultures et déposées ailleurs, principalement au sein de ce qui peut être globalement considéré comme des zones humides (Fontijn, 2002, tableaux 10.1; 10.2). Bien que cette étude concerne les Pays-Bas, il semble qu'elle concorde avec la situation d'autres régions. Des conclusions similaires, avec un focus particulier sur les découvertes en cours d'eau et tourbières en Pologne, ont été présentées par J. Woźny (1996). Il montre que la composition des dépôts dans les eaux de l'âge du Bronze et du premier âge du Fer reflète une opposition nette entre les armes et les outils d'un côté et la parure de l'autre (Woźny, 1996, p. 89).

Les publications récentes sur les dépôts de l'âge du Bronze en Pologne reflètent un abandon des interprétations purement économiques et un transfert vers des visions plus complexes incluant des exemples significatifs d'offrandes rituelles (Blajer, 2001, p. 298-299), avec de nombreux exemples en lien avec des contextes en tourbières et cours d'eau (par exemple Woźny, 1996 et 1997). Des cinq sites polonais où ont été découverts des moules, trois étaient des dépôts en tourbière 
(Kiełpino, Gaj Oławski et indirectement Rosko) alors que pour les deux autres, aucune information n'est disponible et des contextes semblables ne peuvent ainsi pas être exclus. Les trois sites à contexte humide connus sont localisés dans une zone basse où le nombre d'outils déposés dans les eaux augmentent à la fin de l'âge du Bronze. Lorsque l'on compare les contextes des moules et des haches, il est clair que les deux ont eu la même signification, c'est-à-dire que les moules ont été traités comme les outils (les haches) et déposés de la même manière [traduction Karim Gernigon].

Mots-clefs : moule métallique, âge du Bronze, dépôt, Pologne, cire d'abeille.

$\mathrm{M}$ ETAL CASTING MOULDS are a fascinating group of artefacts that have been recorded in many areas of Bronze Age Europe, and were designed mostly to produce only one type of artefact. Despite some examples of moulds for ornaments, in Poland, the use of metal moulds is strongly connected with axes production. Moreover, most of the moulds were deposited deliberately in bogs and rivers in a similar way as axes.

A recent find of such a mould from Gaj Oławski in south-western Poland inspired us to bring together a small collection of bronze casting moulds from Poland from five locations. Three of them were discovered at the beginning of the 20th century and two are considered to have been lost during the Second World War.

\section{THE MOULDS}

$\mathrm{D}$ uring an archaeological search for the remains of a Second World War aircraft in the autumn of 2012, which took place north of Oława - a town about $30 \mathrm{~km}$ south-east of Wrocław in south-western Poland (fig. 1), one of the archaeologists was given a half of a metal

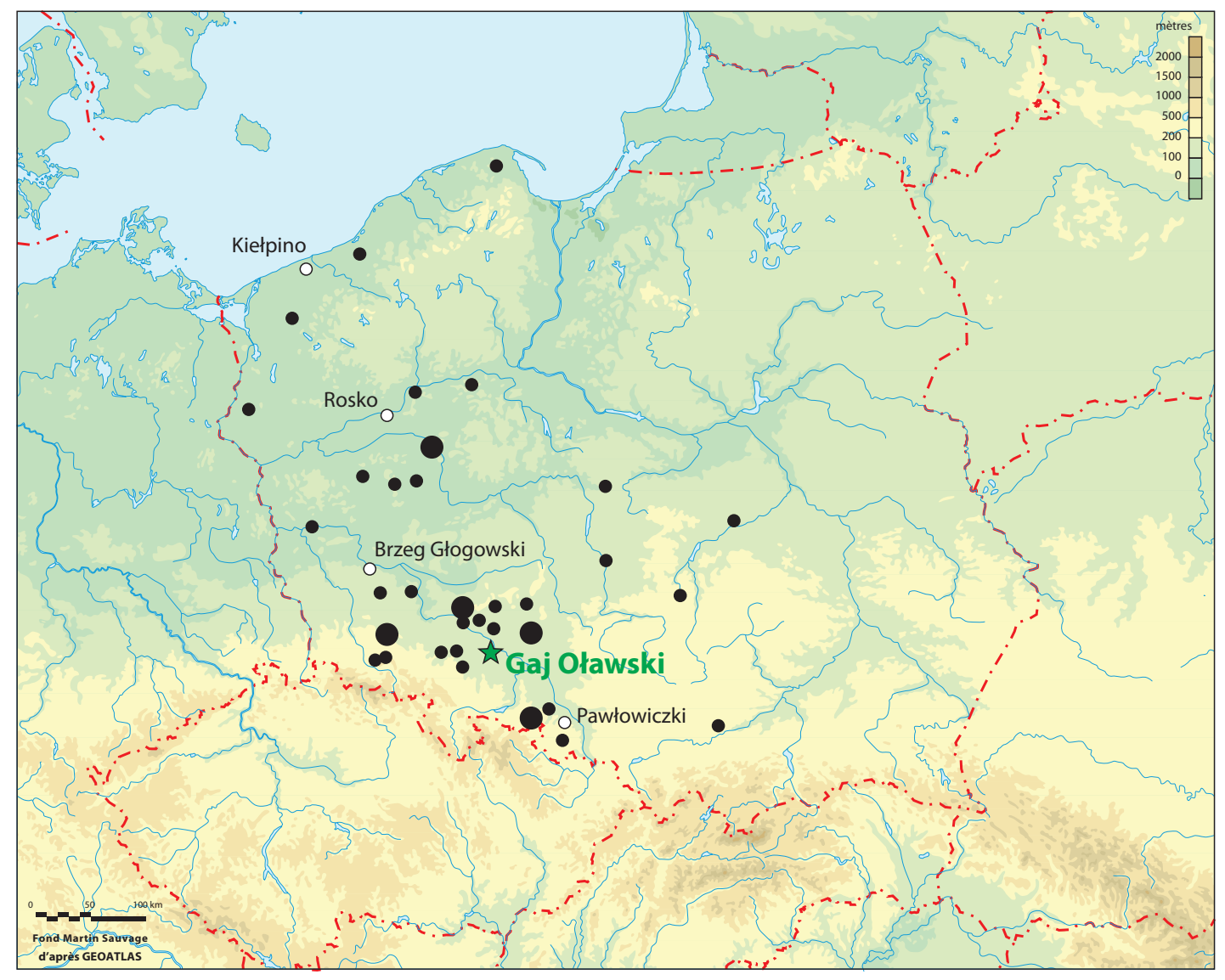

Fig. 1 - Distribution of Bronze Age metal casting moulds and axes of Kowalewko type in Poland. Black spots are the axes (large ones stand for three or more objects found together), white spots are the moulds and green star is the mould from Gaj Oławski (after Kuśnierz 1988, plate 43, modified by J. Baron).

Fig. 1 - Répartition des moules métalliques de l'âge du Bronze et des haches de type Kowalewko en Pologne. Les points noirs représentent les haches (les plus grands représentent une découverte de trois objets ou plus), les points blancs correspondent aux moules, l'étoile verte désigne le moule de Gaj Otawski (d'après Kuśnierz, 1988, pl. 43, modifié par J. Baron). 
casting mould. According to information provided by the founder, the artefact was discovered in the course of a surface survey in 2012, north-west Gaj Oławski village in the Olawa district, at the eastern edge of a ravine of a small, nameless stream. The whole area is now relatively flat and wet with a number of small streams both of natural and artificial origin. No archaeological location was previously recorded there, although some traces of prehistoric settlements are known in the vicinity.

The paper aims to present several bronze casting moulds with a particular focus on the mould discovered recently at Gaj Oławski in south-western Poland. This category of artefacts is rare, both in Polish and in Central European contexts. To date, only six complete two-piece moulds from five Polish locations are known (fig. 1).

The discussed artefact is a half of a casting mould designed for the production of socketed axes. This is an example of a durable, two-piece wedge-shaped mould. The surface is covered with a green patina and number of corrosion marks (fig. 2). The mould measures $17.5 \times 7.2$ $\times 4 \mathrm{~cm}$, while the axe was designed to be $15.6 \mathrm{~cm}$ long with a socket diameter of $3.5 \mathrm{~cm}$ and a maximum blade width of $4 \mathrm{~cm}$ (fig. 3). The weight of the item was $629.3 \mathrm{~g}$.

On the inner side, at the negative edge, four pegs were evident, which most likely fitted into four holes in the lost part of the mould. The pegs were used to join and stabilize both elements during the casting. Also on the inner side, two heavily corroded knobs of unknown function were observed. Perhaps they helped with tying together both elements of the mould or were used to open the still hot mould after the item had been cast. Such a function is sometimes given to outer loops, which often occur on moulds found in Western Europe (e.g., Armbruster, 2000, p. 41).

The negative proves that the mould was used to cast socketed axes of the so-called 'Lusatian type' with a loop, and an oval socket in cross section. The part between the cylindrical socket and the wedge-shaped axe blade is one of the typical characteristic of such axes (Kuśnierz, 1998, p. 25). This type is the most frequent ones of socketed axes known from Poland (Kuśnierz, 1998, p. 25). Due to the axe's size and its decoration, it may be identified as Kowalewko type, variant B. Such axes often occur in deposits, and less frequently in graves and are dated to the 4th period of the Bronze Age (ca. 1100-900 BC) (Kuśnierz, 1998, p. 30). They occur mostly in Lower Silesia (south-western Poland), with some examples from West Pomerania and western Great Poland (west Poland). A few were also found in Brandenburg, Bohemia and Lusatia (Kuśnierz, 1998, p. 31).

\section{OTHER BRONZE MOULDS FROM POLAND}

M etal casting moulds are very rare in Poland with only five examples of such finds known to date. Their distribution is random even if the sites occur only in western Poland they are too few to speak of any pattern of deposition (fig. 1). In the next paragraphs, the moulds from the other sites are briefly presented.

\section{Pawłowiczki, Kędzierzyn-Koźle district}

A complete, two-piece item from Pawłowiczki-probably part of a deposit - was found in 1869; however, the precise location is unknown. Both pieces were of similar size: $12.7 \mathrm{~cm}$ long, $5 \mathrm{~cm}$ wide and 1.8 thick and were designed to cast socketed axes decorated with three vertical grooves (fig. 4a). The two elements were joined together with three projections - two situated at the longer edges of the mould and one at the blade of the axe. The axe cast in this mould could have measured $9.3 \mathrm{~cm}$ in maximum length with a maximum blade width of $3.3 \mathrm{~cm}$. Despite the ornament, which is typical for these artefacts, H. Seger considered it a rare type due to the low loop location (Seger, 1909, p. 24). Based on the axe's characteristics, the mould can be dated to the 5 th period of the Bronze Age (i.e. ca. 900-700 BC).

\section{Brzeg Glogowski, Głogów district}

At Brzeg Głogowski, a complete two-piece mould was found, however no details of its discovery are known (Seger, 1927, p. 62). Both pieces were $13.8 \mathrm{~cm}$ long, $4.2 \mathrm{~cm}$ wide while their thickness is unknown (figs. 4b-c). The mould elements were joined together with five projections - four situated along the mould edge and one at the blade. Together with the mould, a complete socketed axe was found $-10.8 \mathrm{~cm}$ long and $2.8 \mathrm{~cm}$ wide with a socket outer diameter of $3 \mathrm{~cm}$, which had been cast in this mould (fig. 4d). As at Pawłowiczki, this mould can be dated to the 5th period of the Bronze Age (i.e. ca. 900-700 BC).

\section{Kielpino, Gryfice district}

The bog hoard from Kiełpino was discovered in 1884, and among a number of bronze ornaments and elements of horse gear, an iron knife and a lump of iron ore, there were also two complete two-piece moulds and two socketed axes that fitted them (Ebert, 1926, p. 14-15, plate 10). Both the moulds and the axes were much smaller than the other artefacts presented in this paper. One of the moulds was $5.6-5.8 \mathrm{~cm}$ long and $3.2-3.5 \mathrm{~cm}$ wide at the blade part (fig. $4 \mathrm{e}$ ). The second one was smaller: $4.9-5.1 \mathrm{~cm}$ long and $2.7 \mathrm{~cm}$ wide (fig. $4 \mathrm{~g}$ ). The axes were also small — one was $4.4 \mathrm{~cm}$ long, $3 \mathrm{~cm}$ wide with a socket outer diameter of $2.2 \mathrm{~cm}$ (fig. $4 \mathrm{f}$ ) and the other one was only $3.6 \mathrm{~cm}$ long, $2.5 \mathrm{~cm}$ wide and its socket outer diameter was $1.9 \mathrm{~cm}$ (fig. $4 \mathrm{~h}$ ).

Unlike the other moulds, the moulds from Kiełpino were very thin and precisely reflect the shape of the cast axes including the side loops. They were also provided with small handles (ca. $1.5 \mathrm{~cm}$ long in both cases) which make them similar to finds from Western Europe (e.g., Cordier, 1962, fig. 1; Butler and Streegsta, 20052006 , p. 207-240, fig. 107). The deposit is dated to the transitional period between the Bronze and the Iron Age 

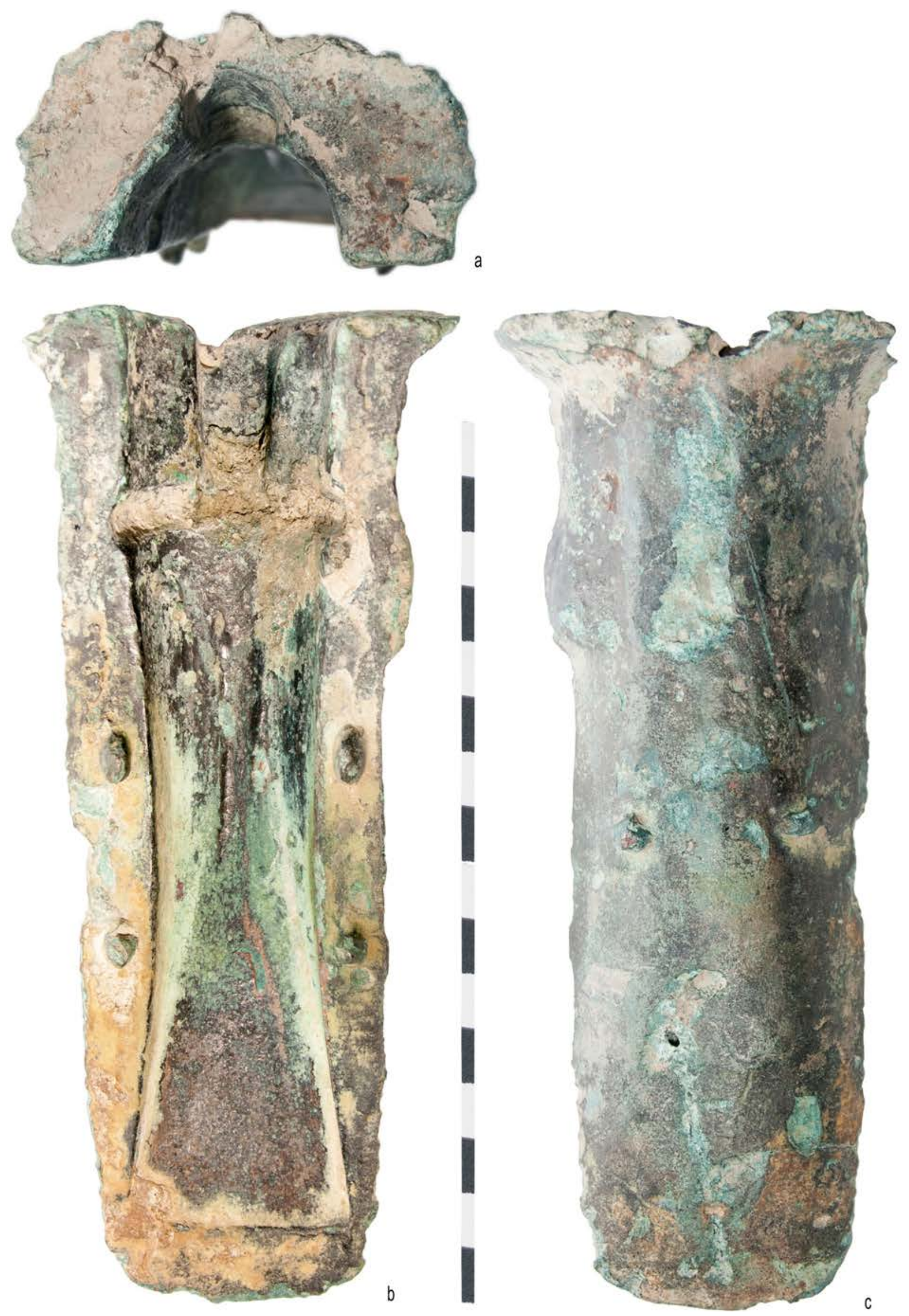

Fig. 2 - Metal casting mould from Gaj Oławski in south-western Poland (photo by Ł. Kapa).

Fig. 2 - Moule métallique de Gaj Oławski, Sud-Ouest de la Pologne (cliché Ł. Kapa). 


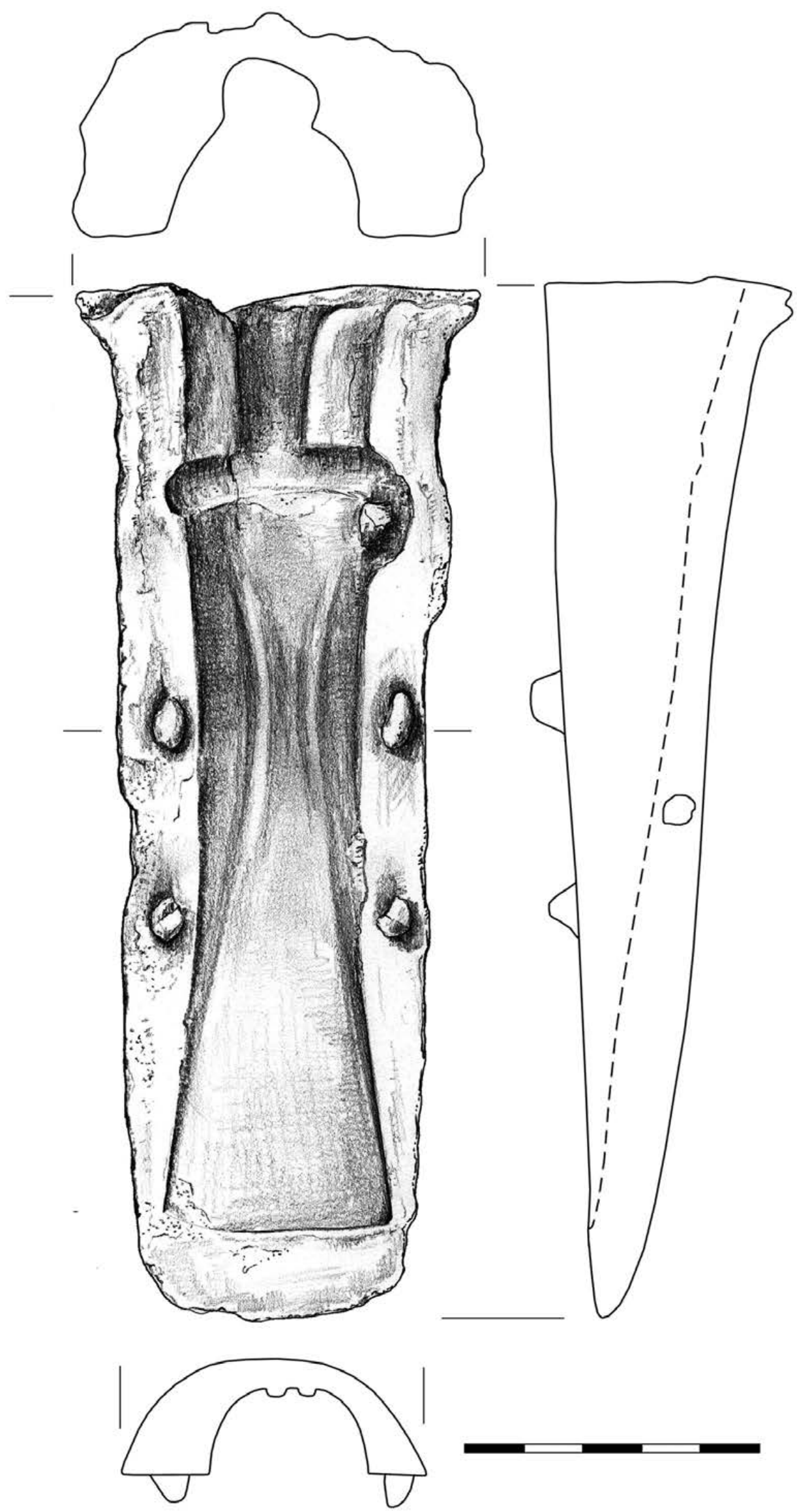

Fig. 3 - Metal casting mould from Gaj Oławski in south-western Poland (drawning N. Lenkow).

Fig. 3 - Moule métallique de Gaj Otawski, Sud-Ouest de la Pologne (dessin N. Lenkow). 

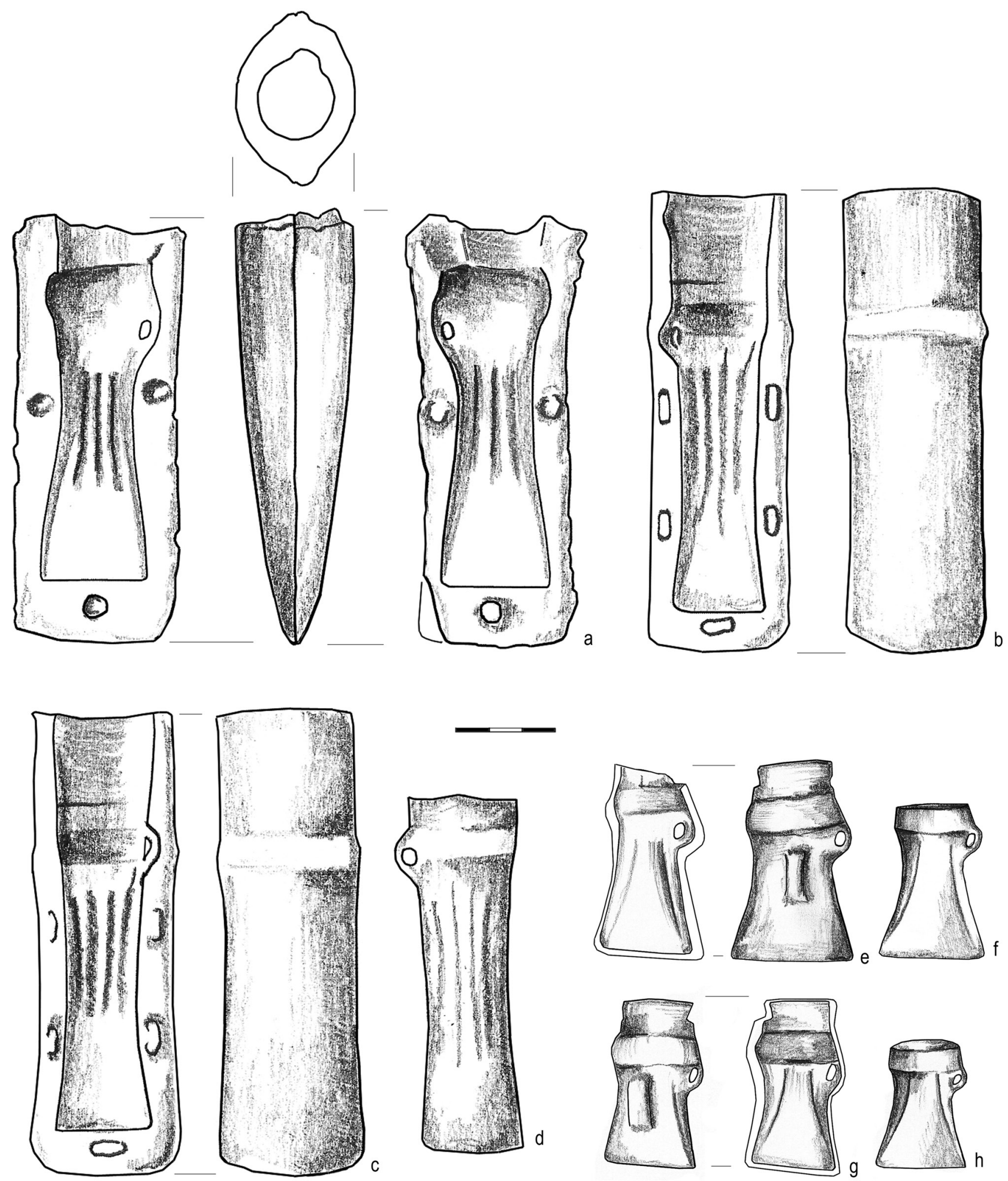

Fig. 4 - Metal casting moulds from Poland. a: Pawłowiczki; b-d: Brzeg Głogowski; e-h: Kiełpino (after Seger, 1909 and 1927 ; Ebert 1926; redrawn by J. Baron).

Fig. 4 - Moules métalliques de Pologne. a : Pawtowiczki; b-d : Brzeg Gtogowski; e-h : Kietpino (d'après Seger, 1909 et 1927; Ebert, 1926; redessinés par J. Baron). 
(i.e. 8-7th century $\mathrm{BC}$ ) with clear inspiration from the Late Bronze Age style (Ebert, 1926, p. 15).

\section{Rosko, Czarnków-Trzcianka district}

Several finds from Rosko were reported as early as the 1930 s, but probably large parts of this hoard were discovered in the course of various construction activities first in 1985 , then in 2001. Due to this, the precise original number of items originating from this deposit remains unknown, and to date only 71 have been brought together (full publication in Machajewski and Maciejewski, 2006). None of the items bear traces of use. The hoard location was very interesting as it was under a single mound, $1.5 \mathrm{~m}$ high and $10 \mathrm{~m}$ in diameter, constructed of earth and large stones. Both the stone construction and the mound itself were destroyed in the $1930 \mathrm{~s}$, but a probable reconstruction was recently completed on the site (Machajewski, 2005, photo on p. 16). Near the mound, a small stream and a pond were located. The deposit mostly consists of bronze socketed axes decorated with vertical ribs (67 items), and two, two-piece bronze cas- ting moulds (figs. 5 and 6), which makes the deposit an excellent example of selected deposition (cf. Fontijn, 2002 , p. 211-217). None of the axes fit the moulds. One of the moulds was $11.7 \mathrm{~cm}$ long, 3.6 and $3.9 \mathrm{~cm}$ wide and had five pegs (figs. $6 \mathrm{a}-\mathrm{c}$ ). The other one was $12.9 \mathrm{~cm}$ long, 3.7 and $4.3 \mathrm{~cm}$ wide, again with five pegs (figs. $6 \mathrm{~d}-\mathrm{f}$ ). Both are interpreted as having been designed for the production of wax models (Machajewski and Maciejewski, 2006, p. 139-140). On one piece, a print of a woven fabric was identified which was the subject of another publication (Sikorski, 2006). The deposit contained mostly axes that were typical for large parts of south-western Poland and may be dated to $c a$. 900-700 BC. The composition both of the moulds and the products were analysed and proved that they had been made of the same type of alloy containing $86.42 \%-91.35 \%$ of copper and $6.86-11.61 \%$ of tin (Machajewski, 2005, p. 19; Sałat et al., 2006). However, there is a significant difference in composition between two halves of one mould (called ' $\mathrm{ON}$ ' and 'ONA'). ON contained $90 \%$ copper, $5.2 \%$ tin and $2.3 \%$ antimony, while ONA contained $87 \%$ copper, $11 \%$ tin and $0.44 \%$ of antimony (Sałat et al., 2006, table 1).

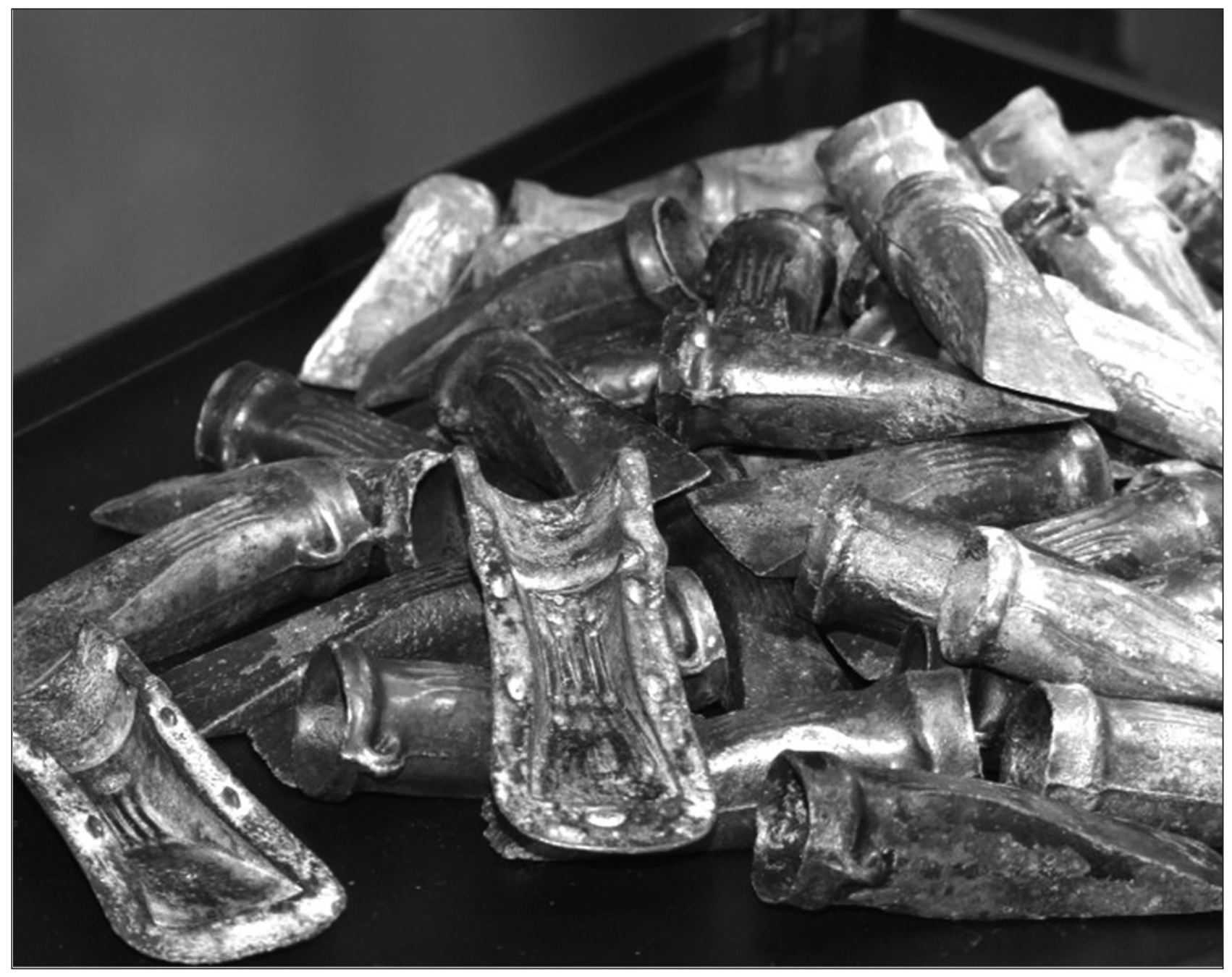

Fig. 5 - Deposit from Rosko (courtesy of the Museum of Piła).

Fig. 5 - Dépôt de Rosko (avec l'aimable autorisation du musée de Piła). 

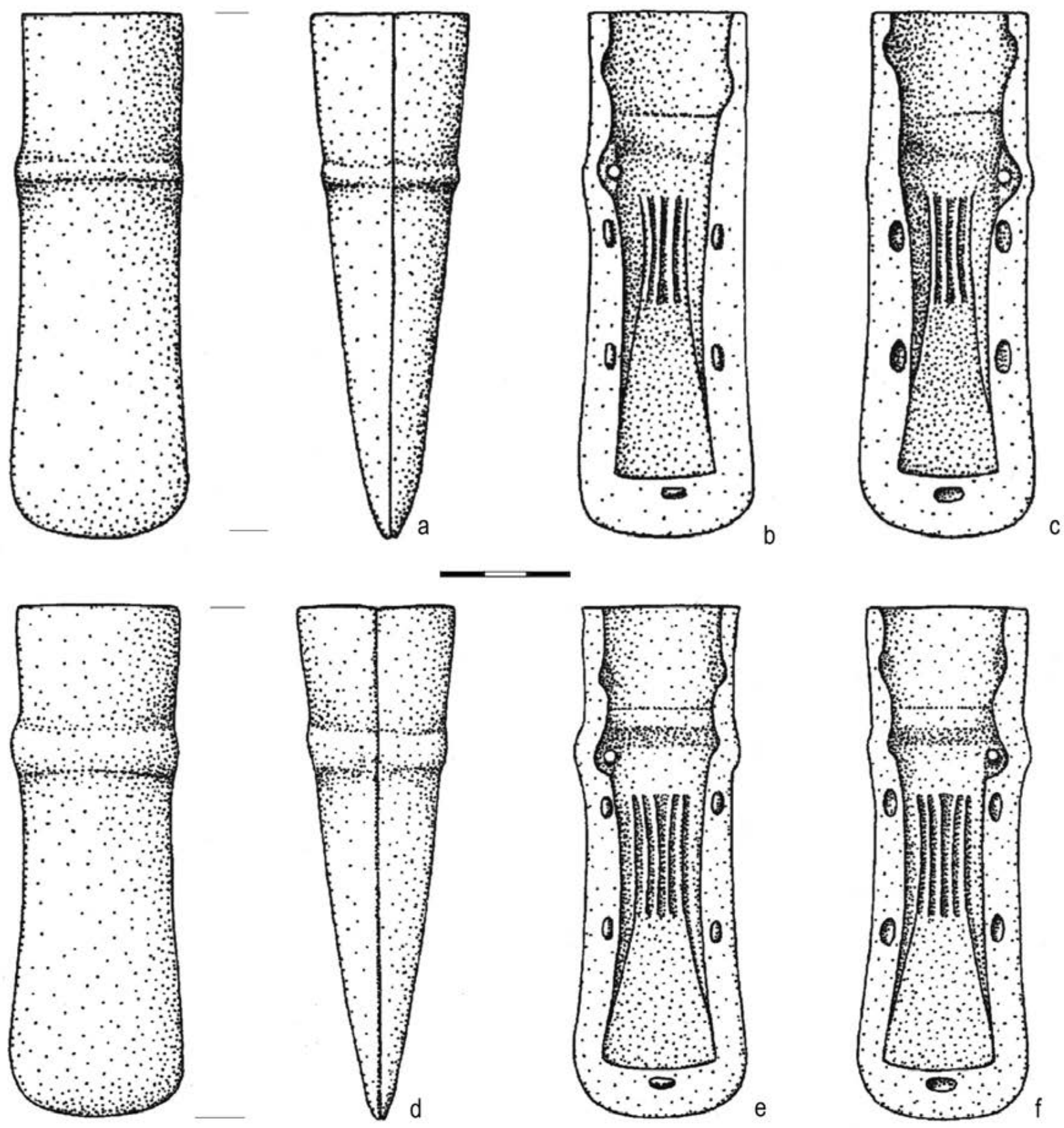

Fig. 6 - Metal casting moulds from the Rosko deposit (after Machajewski, Maciejewski, 2006).

Fig. 6-Moules métalliques du dépôt de Rosko (d'après Machajewski et Maciejewski, 2006).

\section{ARCHAEOMETRIC INVESTIGATION OF THE MOULD FROM GAJ OLAWSKI}

$\mathrm{T}_{\mathrm{t}}^{\mathrm{k}}$

he aim of the archaeometric investigation was to identify both the chemical composition of the mould (including the alloy's main elements and the molecular composition of corrosion layers), and the original purpose of the item. All the analyses were done in the Laboratory for Archaeological Conservation and Archaeometry of the Institute of Archaeology, University of Wrocław. Detailed macroscopic and microscopic observations were performed to observe possible wax remains, which might confirm the production of wax models of axes. The chemical composition was investigated with the use of the XRF, while the analysis was carried out with the use of a Spectro Midex (an X-ray fluorescence spectrometer with energy dispersion). The spectrometer is equipped with a molybdenum X-ray lamp of an excitation energy of $44.6 \mathrm{kV}$ and a Si Drift Detector (SDD) with a resolution of $150 \mathrm{eV}$. For calibration, references from Certified Reference Material BCR 691 of the Institute for Reference Materials and Measurements were used. 


\begin{tabular}{|l|c|c|c|c|c|c|c|}
\hline Sample & $\mathrm{Cu}$ & $\mathrm{Sn}$ & $\mathrm{Sb}$ & $\mathrm{As}$ & $\mathrm{Pb}$ & $\mathrm{Ni}$ & Sum \\
\hline GO1 1 & 90.65 & 4.45 & 1.34 & 0.47 & 0.06 & 0.57 & 97.99 \\
\hline GO1 2 & 90.01 & 5.00 & 1.46 & 0.48 & 0.05 & 0.52 & 98.00 \\
\hline GO1 3 & 89.90 & 5.24 & 1.51 & 0.42 & 0.03 & 0.43 & 97.99 \\
\hline GO1 4 & 89.28 & 5.39 & 1.65 & 0.58 & 0.08 & 0.52 & 97.98 \\
\hline GO1 5 & 88.80 & 5.68 & 1.79 & 0.60 & 0.12 & 0.51 & 97.95 \\
\hline GO1 6 & 88.45 & 5.93 & 1.85 & 0.61 & 0.12 & 0.52 & 97.97 \\
\hline GO1 7 & 88.86 & 5.68 & 1.67 & 0.52 & 0.06 & 0.53 & 97.99 \\
\hline GO1 8 & 77.81 & 14.50 & 4.18 & 1.43 & 0.38 & 0.18 & 99.80 \\
\hline GO1 9 & 84.12 & 10.19 & 3.07 & 0.95 & 0.19 & 0.42 & 99.80 \\
\hline GO1 10 & 88.97 & 5.61 & 1.73 & 0.59 & 0.10 & 0.51 & 97.94 \\
\hline GO1 11 & 87.84 & 6.40 & 1.93 & 0.66 & 0.13 & 0.50 & 97.94 \\
\hline GO1 12 & 88.38 & 6.04 & 1.80 & 0.63 & 0.11 & 0.50 & 97.97 \\
\hline GO1 13 & 90.87 & 5.77 & 1.69 & 0.61 & 0.09 & 0.48 & 99.94 \\
\hline GO1 14 & 85.28 & 10.08 & 2.72 & 0.65 & 0.15 & 0.05 & 99.80 \\
\hline GO1 15 & 88.95 & 5.85 & 1.60 & 0.59 & 0.04 & 0.47 & 97.95 \\
\hline Average & 87.54 & 6.89 & 2.06 & 0.67 & 0.12 & 0.47 & 98.39 \\
\hline Standard deviation & 4.11 & 3.30 & 0.95 & 0.32 & 0.11 & 0.12 & 0.80 \\
\hline
\end{tabular}

Table 1 - Elemental composition of the metal of the casting mould from Gaj Oławski. A number below 100\% results from the lack of quantitative analysis of light elements (e.g. S, P, Si, Al, and Mg).

Tabl. 1 - Composition élémentaire du métal du moule de Gaj Otawski. Le total inférieur à $100 \%$ résulte de l'absence d'analyse quantitative des éléments-traces (par exemple $\mathrm{S}, \mathrm{P}, \mathrm{Si}$, Al et $\mathrm{Mg}$ ).

The data (15 measured points marked as GOl 1-15) from the analysed object obtained on the composition (table 1) enabled us to consider the alloy as rather homogenic (only three samples from the mould rim showed higher tin content). Due to the artefact age and observable corrosion, variability of metal content had been expected, which is well illustrated by measurements of point $\mathrm{GOl} 8(77.81 \% \mathrm{Cu}, 14.5 \% \mathrm{Sn}$ and $4.18 \%$

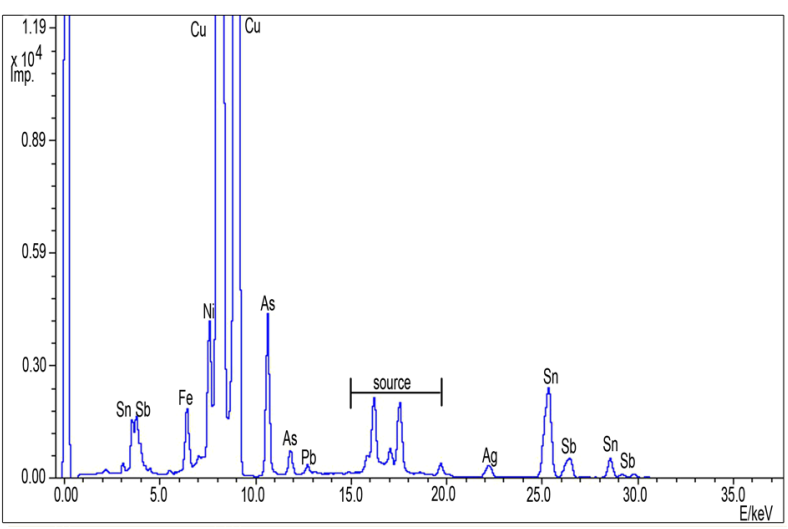

Fig. 7 - The ED-XRF spectrum of the mould from Gaj Oławski (sample Gol 11). Range 15-20 keV reflects the XR lamp interference.

Fig. 7 - Spectre ED-XRF du moule de Gaj Otawski (échantillon Gol 11). L'intervalle 15-20 keV reflète l'interférence de la lampe XR.
$\mathrm{Sb})$ and GOl $13(90.87 \% \mathrm{Cu}, 5.77 \% \mathrm{Sn}$ and $1.69 \% \mathrm{Sb})$. Regardless the diversity of particular metal content, the mould was made of tin bronze (fig. 7), similar to the analysed mould from Rosko (called 'ON'; Sałat et al., 2006).

Further analysis was done with the use of infrared spectroscopy. The sample was prepared using the potassium bromide pellet method. After the removal of contamination from the sample, several milligrams of a black substance was crushed and homogenized. Next, the $10 \mathrm{mg}$ of the sample was mixed with $200 \mathrm{mg}$ of spectral $\mathrm{KBr}$ in an agate mortar. The mixture of the sample and $\mathrm{KBr}$ was pressed at a pressure of about 10 tons to form a transparent pellet. The pellet was transferred quickly to the FT-IR spectrometer for analysis. FT-IR spectroscopy was performed using a Thermo Nicolet 380 spectrometer with Omnic software. Single beam spectra $\left(4000-400 \mathrm{~cm}^{-1}\right)$ of the samples were obtained against air as a background, to present the spectra in absorbance units at a resolution of 1 to $8 \mathrm{~cm}^{-1}$ and $16-64$ scans.

The specimen containing products of oxidation of bronze alloy exhibited traits typical for copper carbonates. Having in mind that the typical corrosion products of bronzes are copper and tin oxides and carbonates: cuprite, malachite, azurite, tin oxides: casserite and romarchite (Scott, 1994), the presence of malachite (hydroxycarbonate of copper $\mathrm{Cu}_{2} \mathrm{CO}_{3}(\mathrm{OH})_{2}$ ) is not a surprise. Its presence is also confirmed by chemical signatures of the carbonic hydroxyl group constituting a series of characteristic peaks. The IR absorption spectrum of malachite shows sharp and distinct bands at 818, 879, 1047, 1099, 


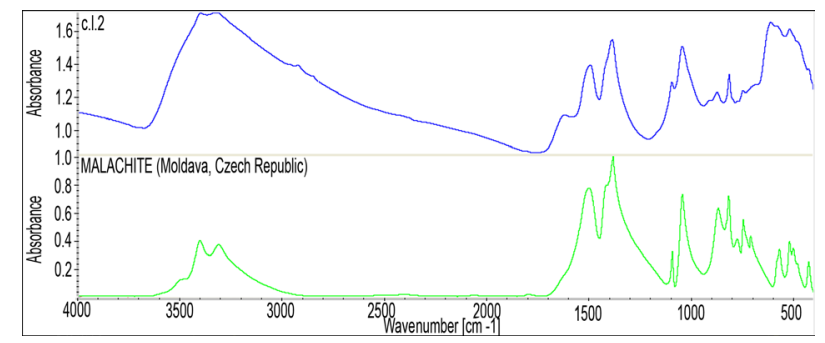

Fig. 8 - The FT-IR spectra of specimen sampled from corroded material from the mould (c.1. 2) and malachite (HR Inorganic).

Fig. 8 - Spectres FT-IR des spécimens échantillonnés sur $d u$ matériau corrodé venant du moule et de malachite (HR inorganique).

1398, 1494, 3330 and $3406 \mathrm{~cm}^{-1}$ (Aliatis et al., 2009, p. 532-538). Figure no. 8 shows the IR spectrum of the specimen sampled from the mould with all the signatures present. Moreover, the spectrum was compared and confirmed with a malachite spectrum pattern (HR Inorganic database).

Further analysis focused on the original purpose of the mould i.e. to answer the question what kind of material was poured into the mould. To achieve this, a specimen was sampled from the area of a smooth, semi-glossy spot (3-4 $\mathrm{mm}$ in diameter) situated by the parallel ribs and contrasting with the oxidized mould's inner surface (fig. 9). The investigated residue was a black, soft paste with a characteristic wax-like gloss. From the specimen, a pellet (only $2 \mathrm{mg}$ were sampled which — together with the age of the material - influenced the intensity of obtained signals in the IR spectrum) was formed which then was investigated under a changing resolution, varying from 8 to $1 \mathrm{~cm}^{-1}$. In the course of analysis, a spectral IR image showing signatures of mineral substances was obtained (fig. 10). A search in the available databases (HR Inorganic, US Geological Survey) allowed us to identify three minerals: bentonite $(\mathrm{Na}, \mathrm{Ca})_{0.33}(\mathrm{Al}, \mathrm{Mg})_{2} \mathrm{Si}_{4} \mathrm{O}_{10}(\mathrm{OH})_{2} \cdot \mathrm{nH}_{2} \mathrm{O}$ (usually indicated as a raw-material for pottery production), chalcosiderite $\mathrm{CuFe}_{6}\left(\mathrm{PO}_{4}\right)_{4}(\mathrm{OH})_{8} \cdot 4 \mathrm{H}_{2} \mathrm{O}$, and chrysocolla $(\mathrm{Cu}$, $\mathrm{Al})_{2} \mathrm{H}_{2} \mathrm{Si}_{2} \mathrm{O}_{5}(\mathrm{OH})_{4} \cdot \mathrm{nH}_{2} \mathrm{O}$. Apart from inorganic compounds, bands from the vibrations of hydrocarbons - possibly indicating natural waxes or resins were identified (Lucejko et al., 2012, p. 110-118). These signatures, although very weak, are visible after subtracting the spectra in the following areas: $c a$. 3000, 1700, 1500-1350, $700-800 \mathrm{~cm}^{-1}$. According to previous macroscopic observations, the focus was on possible ancient beeswax remains. The available results of the analyses of archaeological waxes (e.g., Bakr et al., 2005; Latuatti-Derieux et al., 2009; IRUG Database) allowed us to state that the beeswax IR-signals are: 2955, 2918, 2849, 1462, 1737, 729 and $719 \mathrm{~cm}^{-1}$ (Kovala-Demertzi et al., 2012) and 3428, 2952, 2915, 2844, 1735, 1467, 1375, 1195, 1172, 729 and $721 \mathrm{~cm}^{-1}$ (Luo et al., 2012). J. Lucejko et al. (2012) argues that wax content is confirmed with a signal of $1460 \mathrm{~cm}^{-1}$. The analysed specimen gave such signals as: $3411,2948-2924-2853,1733,1464,1388,1165$, 730 and $709 \mathrm{~cm}^{-1}$ corresponding well with the identified archaeological samples of beeswax (fig. 11).

\section{DISCUSSION}

\section{Were these moulds used for wax or metal casting?}

There are two types of data obtained for the mould from Gaj Oławski. One group refers to the mineralogical composition of the item and proved the relatively low tin content (table 1) which is far from Bronze Age 'standards' of ca. $10 \%$. This may correspond with the opinion that the axes - regarding the alloys and casting techniques — display relatively lower quality than weapons or ornaments
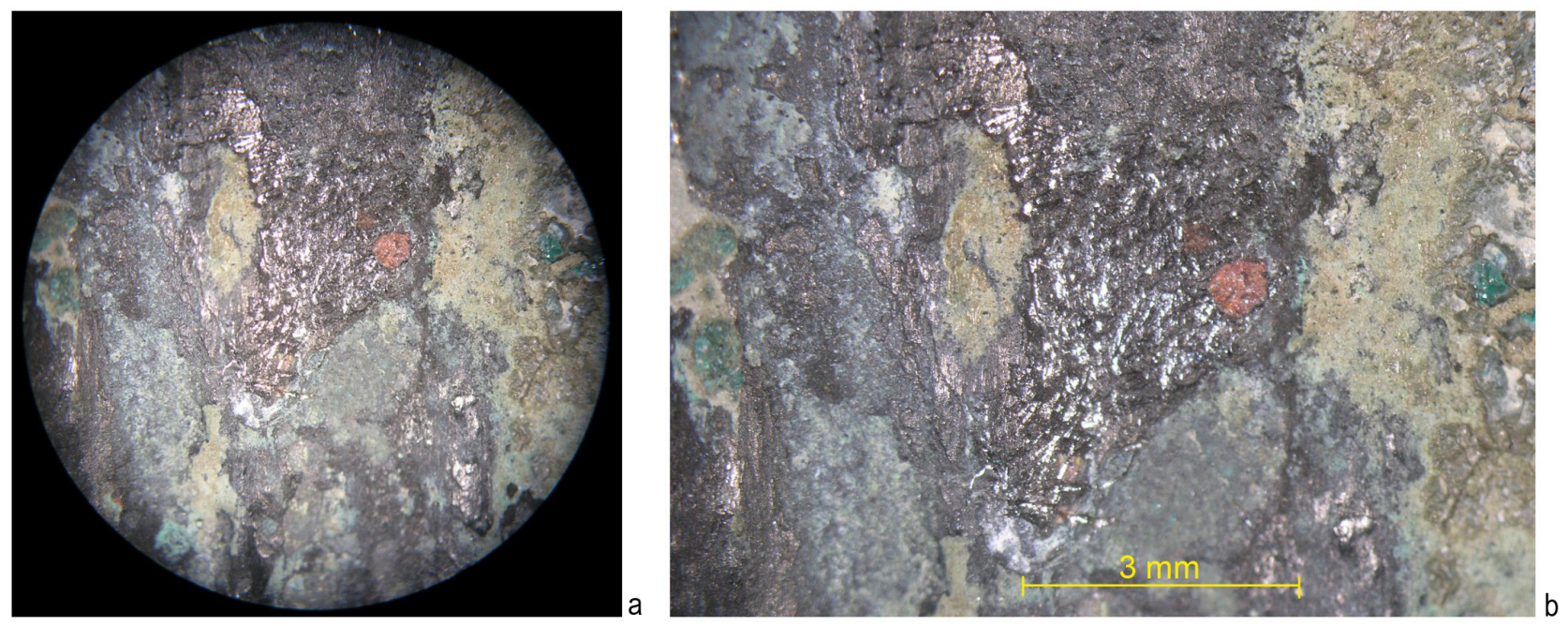

Fig. 9 - Microscopic image of the mould. A shiny black area in the central part was sampled for FT-IR tests.

Fig. 9 - Image microscopique du moule. L'aire noire et luisante dans la partie centrale a été échantillonnée pour les tests FT-IR.. 


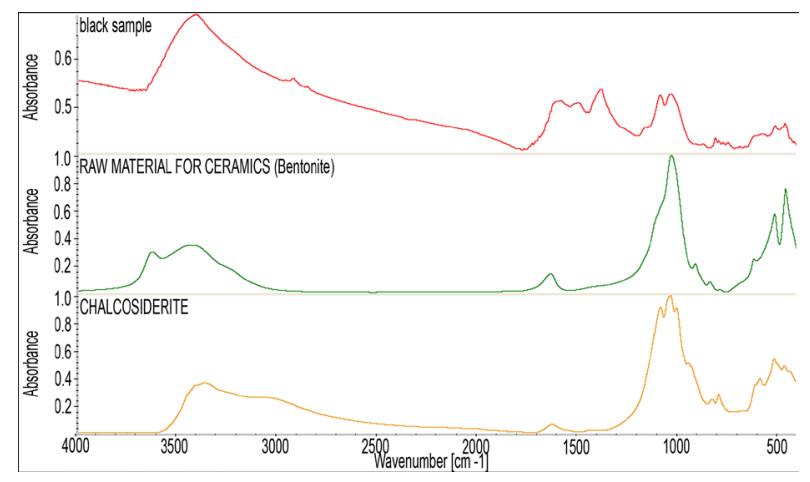

Fig. 10 - FT-IR spectra of investigated specimen and identified minerals.

Fig. 10 - Spectres FT-IR du spécimen analysé et minéraux identifiés.

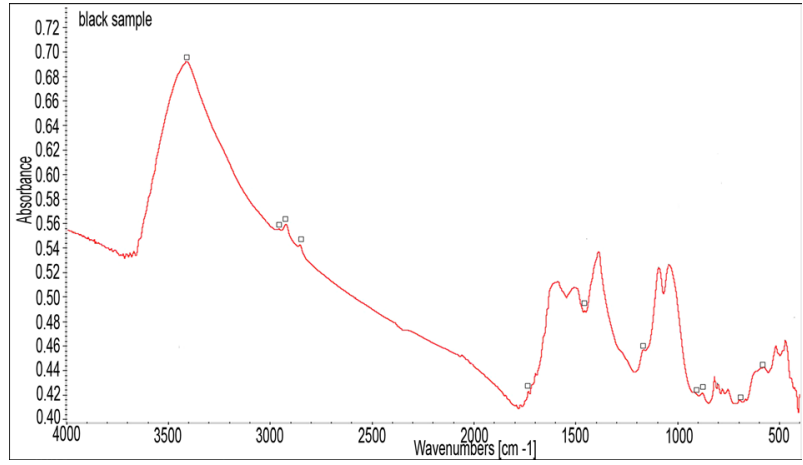

Fig. 11 - FT-IR spectrum of investigated specimen. The squares mark signals of beeswax.

Fig. 11 - Spectre FT-IR du spécimen analysé. Les carrés indiquent les signaux de cire d'abeille.

(e.g., Sałat et al., 2006, p. 150). From this perspective, the moulds and the axes represent the same 'kind' of artefacts. This also fits the opinion that the low tin content may indicate a better resistance against high temperatures and direct metal casting.

The other group of data refer to the black residue from the mould which is beeswax remains. This appears to confirm that bronze moulds were used in in the production of wax models, not metal items. Can these two set of data and thus two opinions be combined? Alternatively, was the mould a multi-purpose tool?

According to an opinion that is common also in Polish literature, metal casting moulds, due to their low resistance to high temperatures, were used exclusively for making wax or lead models and not for producing bronze products themselves (e.g., Kostrzewski, 1953, p. 193; Dobrzańska, 1959, p. 90; recently Machajewski and Maciejewski, 2006, p. 142). The similar composition (the tin content in particular) of both the moulds and products are considered to preclude direct casting (Machajewski, 2005, p. 19). Although both moulds and axes were found at Kiełpino, Brzeg Głogowski and Rosko, only the latter one was analysed in terms of the mineral composition while the first one is considered to have been lost during the last war. The data for Rosko proved that there is no direct and simple correspondence between the moulds and axes' composition, as both types of artefacts are not homogeneous and vary significantly in their particular tin and antimony content-even in one, two-piece artefact (Sałat et al., 2006, table 1).

Some experimental work proved that the metal moulds could have been used successfully in the production of bronze artefacts, and when controlled in terms of temperatures, did not get broken in the course of casting. The process has been already described in detail in several papers and thus will not be discussed here (e.g., Mohen, 1978, p. 27 with further literature therein).

The mould from Gaj Oławski displays properties allowing it both to have cast metal (low tin content) and wax (beeswax remains), which makes it a good example of a multi-purpose tool used in various conditions. It also proves that bronzesmiths had great flexibility while working on metal or wax. It must be noticed here, bronze moulds are considered to be designed rather for mass production of axes which excludes use of single-use wax models. Fired organic coatings, mostly charcoal, could have been used as a layer preventing the welding of mould with poured liquid metal, and the wax can represent the remnants of such coating (which would mean that the mould was covered with coating but was not fired). Alternatively, wax could have been used to protect the mould surface from corrosion as metal moulds are considered to be highly-valued items (Kujipers, 2008, p. 89).

\section{Distribution and context}

Bronze moulds, mostly designed for production of axes, have been discovered in large parts of Europe, but it is not possible to identify any clear distribution pattern, although one concentration may be noticed in north-east France (Mohen, 1978, fig. 7). Three such objects for casting axes (but none complete) are known from the Netherlands, while two of them were found in a wet environment and, based on the context were interpreted as votive offerings. They are dated to the Late Bronze Age (Kuijpers, 2008, p. 89, appendix 2). Similar moulds of mostly the same chronology are known from Spain, France and the British Islands (e.g., Cordier, 1962; Mohen, 1978; Fleury, 1991, p. 269-270; Armbruster, 2000). A few have been found in the Czech Republic, Slovakia and Hungary, however, their exact number and contexts are rather confused (Kosařova, 2009, p. 75). Probably the best documented are moulds from deposit II from Velim, ca. $60 \mathrm{~km}$ east of Prague, where three bronze two-piece items for axes were found (Hrala, 2000, p. 222-223). The location itself is very interesting as the deposit was one of seven hoards found at the cult site of 'Skalka' [The Rock] at Velim, accompanied by a system of ditches filled with hundreds of human bones (Hrala et al., 2000).

Considering the context and the interpretation, the discussion on bronze casting moulds is strongly connected with the discussion on bronze deposits in general. 
The known locations allow us to consider the bronze casting moulds as objects of deliberate, and usually selective deposition, mostly in what can be described as 'offering contexts', including river, bog and hilltop finds. In his detailed study on depositional patterns and contexts, D. Fontijn argues that axes, sickles and weapons were kept away from graves, deposited somewhere else, mostly in what may be broadly understood as 'wet areas' (Fontijn, 2002, tables 10.1 and 10.2). Although his study concerns the Netherlands, it seems to fit the situation from other areas as well. Similar conclusions with a particular focus on river and bog finds in Poland were presented by J. Woźny (1996). He argues that the composition of water deposits in the Bronze and Early Iron Age in Poland reflects a clear opposition between weapons/ tools and ornaments (Woźny, 1996, p. 89).

Recent publications on bronze deposits in Poland reflect a move away from purely economic interpretations to more complex views including significant examples of 'votive offerings' (Blajer, 2001, p. 298-299), with many examples connected with bog and river contexts (e.g., Woźny, 1996 and 1997). Among water deposits, 56\% can be dated to the Late Bronze, Early Iron Age (Blajer, 2001, fig. 38) which is interpreted as reflecting mostly ritual activities (Blajer, 2001, p. 288).

Among five Polish sites with the moulds, three were bog deposits (Kiełpino, Gaj Oławski, and indirectly Rosko) while for the other two, no information is available and thus similar contexts cannot be excluded. The three sites with known water contexts are located in a lowland area where the number of tools deposited in water increase towards the end of the Bronze Age (Woźny, 1997, p. 38; Blajer, 2001, fig. 38). When the contexts of the moulds and axes are compared, it is clear that both were given similar significance, i.e. the moulds were treated like tools (axes) and deposited in the same way. This convergence corresponds well with the results of the archaeometric investigation that proved the similar mineralogical composition of moulds and axes from Rosko - both types of artefacts are made of similar heterogeneous alloys (Sałat et al., 2006, table 1).

The last find of the mould from Gaj Oławski and older finds, some published over 100 years ago seem to be an interesting category of finds based on various aspects including their use and mode of deposition.

\section{CONCLUSIONS}

$T$ he bronze moulds from Poland complete the list of previously known bronze casting moulds from other parts of Europe. They seem to share the same characteristics including the destination of the moulds which was the axe production.

Although very limited data are available, at least one mould (from Gaj Oławski) can be called a multi-purpose tool used both for metal casting (indirectly proven by the low tin content) and for wax model production. If we deny use of wax models for axes, the beeswax remains may be considered as organic coating, which could have been used as a layer preventing the welding or to protect the mould surface from corrosion.

In terms of context, three of the five locations were bog deposits. Observations of contexts from other parts of Europe allow us to say that the meaning and thus the deposition pattern was the same for moulds and ready axes and other tools.

\section{BIBLIOGRAPHY}

Aliatis I., Bersani D., Campani E., Casoli A., Lottici P. P., Mantovan S., Marino I.-G., Ospitali F. (2009) - Green pigments of the Pompeian artists' palette, Spectrochimica Acta Part A: Molecular and Biomolecular Spectroscopy, 73, pp. 532-538.

Armbruster B. R. (2000) - Goldschmiedekunst und Bronzetechnik. Studien zum Metallhandwerk der Atlantischen Bronzezeit auf der Iberischen Halbinsel, Montagnac, Monique Mergoil (Monographies instrumentum, 15), $231 \mathrm{pp}$.

Bakr Mossa A., Kawiak T., Pawlikowski M., SawloWICZ Z. (2005) - Characterisation of 15 th century red and black pastes used for wall decoration in the Qijmas El-Eshaqi mosque (Cairo, Egypt), Journal of Cultural Heritage, 6, pp. 351-356.

BLAJER W. (2001) - Skarby przedmiotów metalowych z epoki brąu $i$ wczesnej epoki żelaza na ziemiach polskich, Kraków, Uniwersytet Jagielloński w Krakowie, 427 pp.

Butler J. J., Steegstra H. (2005-2006) - Bronze Age Metal and Amber in the Netherlands (III:2). Catalogue of the socketed axes, part C, Palaeohistoria, 47-48, pp. 207-240.
Cordier G. (1962) - Quelques moules de l'âge du Bronze provenant de la Touraine et du Berry, Bulletin de la Société préhistorique française, 59, 11-12, pp. 838-849.

DobrzaŃsKa E. (1959) - Przyczynek do znajomości metalurgii brązowej w epoce brązu i okresie halsztackim w dorzeczu górnej Wisły i górnej Odry, Silesia Antiqua, 1, pp. 83-102.

EBert M. (1926) - Reallexikon der Vorgeschichte, VII, Berlin, Walter De Gruyter, pp. 14-15.

FLeury L. (1991) - Moules de l'âge du Bronze en France atlantique et dans les îles Britanniques : aspects techniques et culturels, in C. Chevillot and A. Coffyn (eds.), L'Âge du Bronze atlantique : ses faciès, de l'Ecosse à l'Andalousie et leurs relations avec le Bronze continental et la Méditerranée, procceedins of the first congress held in the Parc archéologique de Beynac, Beynac-et-Cazenac, Association des musées du Sarladais, pp. 269-270.

FonTIJn D. R. (2002) - Sacrificial landscapes. Cultural biographies of persons, objects and 'natural' places in the Bronze Age of the southern Netherlands, ca. 2300-600 BC, Leiden, University of Leiden (Analecta Praehistorica Leidensia, 33-34), $392 \mathrm{pp}$. 
Hrala J. (2000) - Metal artefacts and artefacts of other materials, in J. Hrala, R. Šumberová \& M. Vávra (eds.), Velim. A Bronze Age fortified site in Bohemia, Praha, pp. 222-223.

Hrala J., Šumberová R., Vávra M. (2000) - Velim. A Bronze Age fortified site in Bohemia, Praha, Institute of Archaeology, Academy of Sciences of the Czech Republic, 347 pp.

IRUG Database, http://www.irug.org/ed2k/search.asp

KosaŘova Z. (2009) - Odlévací formy mladši doby bronzové $z$ oblasti středního Podunají, masters thesis, Masarykova univerzita v Brně, Brno, pp. 75.

Kostrzewski J. (1953) - Wytwórczość metalurgiczna w Polsce od neolitu do wczesnego okresu żelaznego, Przegląd Archeologiczny, 9, pp. 177-213.

Kovala-Demertzi D., Papathanasis L., Mazzeo R., Demertzis M. A., Varella E. A., Prati S. (2012) - Pigment identification in a Greek icon by optical microscopy and infrared microspectroscopy, Journal of Cultural Heritage, 13, pp. 107-113.

KuiJPers M. H. G. (2008) - Bronze Age Metalworking in the Netherlands (C. 2000-800 BC). A Research into the Preservation of Metallurgy Related Artefacts and the Social Position of the Smith, Leiden, Sidestone, $89 \mathrm{pp}$.

KuŚnierz J. (1998) - Die Beile in Polen III (Tüllenbeile), Stuttgart, Franz Steiner (Prähistorische Bronzefunde, 9, 21), pp. $25,30-31$.

Lattuati-Derieux A., Egasse C., Regert M., Chung YongJae, LAVÉdRINE B. (2009) - Characterization and degradation pathways of ancient Korean waxed papers, Journal of Cultural Heritage, 10, pp. 422-427.

Luo W., Li T., Wang C., Huang F. (2012) - Discovery of Beeswax as binding agent on a 6th-century BC Chinese Turquoise-inlaid Bronze sword, Journal of Archaeological Science, 39, pp. 1227-1237.

Łucejko J.-J., Lluveras-Tenorio A., Modugno F., RibeCHINi E., Colombini M. P. (2012) - An analytical approach based on X-ray diffraction, Fourier transform infrared spectroscopy and gas chromatography/mass spectrometry to characterize Egyptian embalming materials, Microchemical Journal, 103, pp. 110-118.

Machajewski H. (2005) - Brązowy skarb z Roska, Archeologia Żywa, 3, 33, pp. 16-19.

Machajewski H., Maciejewski M. (2006) - Skarb ludności kultury łużyckiej z Roska nad Notecią, in H. Machajewski \& J. Rola (eds.), Pradolina Noteci na tle pradziejowych $i$ wczesnośredniowiecznych szlaków handlowych, Poznań, pp. 127-146.

Mohen J.-P. (1978) - Moules en bronze de l'âge du Bronze, Antiquités nationales, 10, pp. 23-32.

Satat R., Kozakowski S., Krokosz J., Warmuzek M. (2006) - Badania metalograficzne przedmiotów brązowych pochodzących z Roska, gmina Wielen, in H. Machajewski \& J. Rola (eds.), Pradolina Noteci na tle pradziejowych $i$ wczesnośredniowiecznych szlaków handlowych, Poznań, pp. 147-152.
Scotr D. A. (1994) - An Examination of the Patina and Corrosion Morphology of Some Roman Bronzes, Journal of the American Institute for Conservation, 33, 1, pp. 1-23.

SEgER H. (1909) - Beiträge zur Vorgeschichte Schlesiens von Hans Seger: 3. Gussformen, Schlesiens Vorzeit in Bild und Schrift, N. F. V, 5, pp. 16-27.

Seger H. (1927) - Vermehrung der vorgeschichtlichen Sammlung des Schlesischen Museums für Kunstgewerbe und Altertümer, Altschlesien, 2, 1, pp. 59-68.

SiKORSKI (2006) - Wyrób sprangowy na brązowej formie do odlewu siekierek z Roska, in H. Machajewski \& J. Rola (eds.), Pradolina Noteci na tle pradziejowych i wczesnośredniowiecznych szlaków handlowych, Poznań, pp. 153-156.

WoŹny J. (1996) - Symbolika wody w pradziejach Polski, Bydgoszcz, Wydawnictwo Uczelniane WSP w Bydgoszczy, $186 \mathrm{pp}$.

WoŹNY J. (1997) - Symbolika depozytów wodnych z epoki brazu na Nizu Polskim [Symbolik der Wasserdeponierungen der Bronzezeit in der polnischen Tiefebene], in W. Blajer (ed.), Beiträge zur Deutung der bronzezeitlichen Hort- und Grabfunde in Mitteleuropa $=$ Przyczynki do interpretacji skarbów i znalezisk grobowych z epoki brąu w Europie Srodkowej, proceedings of the Instytut Archeologii Uniwersytetu Jagiellońskiego (Kraków, 1996), Kraków, Materialen der archäologischen Konferenz „Bronzen und Menschen an der Schwelle der Urnenfelderzeit im Östlichen Mitteleuropa", pp. 33-43.

Justyna BARon

Institute of Archaeology, Wrocław University ul. Szewska 48 50-139 Wrocław, Poland justyna.baron@gmail.com

Beata Miazga Laboratory for Archaeological Conservation and Archaeometry

Institute of Archaeology, Wrocław University ul. Koszarowa 3, bud. 28 51-149 Wrocław, Poland beata.miazga@archeo.uni.wroc.pl

Kamil Nowak

Institute of Archaeology, Wrocław University ul. Szewska 48 50-139 Wrocław, Poland akinakesy@gmail.com 